Sari Pediatri, Vol. 2, No. 1, Juni 2000: $11-22$

\title{
Aspek Hukum KIPI (Kejadian Ikutan Pasca Imunisasi)
}

\author{
Agus Purwadianto
}

Imunisasi secara medis merupakan tindakan yang aman, namun sesekali terancam oleh efek samping atau efek buruk yang disebut KIPI. Dalam bentuk program, imunisasi massal akan memunculkan kekerapan KIPI yang dapat merugikan jasmani dan bahkan nyawa pasien yang semula sebagai klien petugas kesehatan. Hukum, khususnya hukum administrasi negara yang dilandasi oleh etika sosial dan manajemen yang lege artis mengharuskan pejabat kesehatan hingga ke tenaga pelaksana kesehatan melaksanakan program tersebut sehingga tujuan imunisasi tercapai, tanpa menimbulkan gugatan hukum yang tidak perlu dari pasien yang dirugikan akibat KIPI. Efektivitas dan efisiensi program akan seimbang dengan yuridisitas dan legalitasnya. Bila gugatan hukum muncul, kerangka hukum penyelesaian dan perlindungannya terdapat dalam lingkup hukum administrasi negara, yang berbeda dengan hukum kesehatan perorangan. Petugas kesehatan dilindungi oleh standar prosedur operasional, pemberian informed-consent kolektif, pembuatan surat-tugas dan bahkan tindakan diskresioner sesuai dengan kondisi dan situasi lapangan demi kepentingan klien dan pasien. Persyaratan diskresi tersebut secara hukum diuraikan, termasuk rantai tanggungjawabnya hingga ke pejabat tertinggi dalam bidang kesehatan. Pokja KIPI yang berfungsi sebagai lembaga independen dan penasehat pemerintah, dapat berfungsi sebagai lembaga yang memverifikasi fakta hukum, penyelesaian kasus sengketa medik pada KIPI, serta usulan pemberian santuan kepada korban bila diperlukan, sebelum kasus tersebut masuk ke lembaga peradilan resmi yang seringkali justru sulit menciptakan keadilan.

Kata kunci: Imunisasi - hukum administrasi negara - program kesehatan - sengketa medik.

$\mathscr{M}$ araknya kesadaran masyarakat akan hakhaknya, dalam sisi positif termasuk kesadaran terhadap hak atas informasi dan hak penentuan nasib sendiri, mengiringi perkembangan hukum kedokteran dan kesehatan di dunia; sedangkan dari sisi negatif dapat menyebabkan timbulnya beberapa ekses. Ekses tersebut antara lain berupa mulai seringnya dokter diadukan, dituntut atau digugat oleh pasien

Ketua Ikatan Dokter Indonesia Cabang Jakarta, Anggota Pokja KIPI Depkes RI, Staf Pengajar Bagian Forensik FKUI/RSCM Jakarta.

\footnotetext{
Alamat korespondensi:

Dr. Agus Purwadianto,SpKF,SH

Jl. Salemba No. 6, Jakarta 10430, Indonesia.

Telpon: (021) 310 6976. Fax.: (021) 315 4626,

e-mail: Agus_Purwadianto@hotmail.com.
}

(beserta pengacaranya). Ekses ini agaknya "lebih membekas" atau bahkan "mencekam" kalangan dokter dan tenaga kesehatan lainnya, ketimbang berbuat hatihati dan teliti sesuai dengan standar profesi dan standar prosedur operasional. Malahan sebagian dokter bersikap defensif. Reaksi seperti ini secara sosiopsikologis adalah normal, karena para dokter yang selama berabad-abad telah "menikmati" alam kebebasan/otonomi paternalistik (baca : dokter lebih merupakan ayah, sedangkan pasien merupakan anak-anaknya) tiba-tiba didudukkan dalam kesejajaran dengan klien/pasiennya. Terdapat kesan bahwa hukum dianggap mencari-cari kesalahan dokter. ${ }^{1}$ Padahal persepsi tersebut dalam hukum yang adil tidaklah demikian. Justru hukum berfungsi untuk melindungi termasuk tenaga kesehatan yang bersikap profesional dan lege artis, sampai kapan 
Sari Pediatri, Vol. 2, No. 1, Juni 2000

pun dan di mana pun, serta terhadap siapa saja. ${ }^{2}$ Dengan demikian hukum yang adil pun pasti akan melindungi dokter di barisan paling depan (PTT atau Inpres di Puskesmas) beserta tenaga kesehatan bawahannya dari gugatan masyarakat yang terkena atau korban KIPI. Hukum ini pun diwujudkan dan akan selalu dijunjung tinggi oleh pemerintah, termasuk aparat penegak hukumnya seperti kepolisian, kejaksaan, dan aparat lainnya, yang pada gilirannya (bila peradilan tak bisa dihindari), juga oleh hakim di pengadilan.

\section{Kedudukan Hukum}

KIPI ditinjau dari segi medis merupakan fakta empirik yang menyatu dalam suatu fenomena yang disebut tindakan medik. KIPI merupakan side-effect dan atau adverse effect dari tindakan medik berupa imunisasi (pengebalan). Yang dimaksud dengan tindakan medik di sini adalah dalam arti sempit, yakni suatu intervensi terhadap badan (tubuh) dan jiwa klien (pasien) dalam rangka suatu pencegahan, proteksi spesifik, diagnostik, terapi, dan rehabilitasi dalam rangka tujuan medik.

Imunisasi merupakan tindakan medik dalam aspek pencegahan dan proteksi spesifik yang ditujukan kepada orang (anak) sehat, bukan anak sakit, jadi ditujukan kepada klien. Oleh karena itu, hubungan (hukum) yang ada pada tindakan imunisasi adalah hubungan tenaga kesehatan - klien, yang pada peristiwa (hukum) KIPI hubungan tersebut dapat tetap atau segera berubah menjadi hubungan dokter - pasien. Pada KIPI si klien yang semula sehat telah berubah menjadi sakit (disebut pasien), yang bahkan - dalam keadaan tertentu, sebagaimana risiko tindakan medik lainnya - dapat sakit, cacat, fatal, sehingga terdapat gugatan (disebut korban). Kejadian KIPI walaupun amat jarang ${ }^{4}$ dapat terjadi dimana saja, pada siapa saja dan oleh petugas kesehatan siapa saja. ${ }^{3}$ KIPI dapat terjadi pada program imunisasi massal maupun hingga kini masih (hampir semua) dilakukan oleh pemerintah, namun dapat juga ditemukan pada kejadian imunisasi perorangan (oleh dokter atau tenaga kesehatan pada saat praktek swasta). Pada imunisasi massal (menyangkut jutaan orang), secara numerik kemungkinan KIPI akan semakin terungkap ke permukaan. Beberapa di antaranya berpotensi menjadi sengketa medik. Yang dibahas dalam tulisan ini adalah KIPI pada program imunisasi massal yang dilakukan oleh pemerintah.

\section{Tatanan Hukum}

Program imunisasi massal sifat hukumnya adalah hukum publik, yakni menyangkut hubungan hukum (baca kepentingan) antara pemerintah/negara dengan warganegara/penduduknya. Program imunisasi dijalankan sebagai kewajiban (akrab disebut : tugas) pemerintah dalam suatu negara demi kepentingan rakyatnya (dikenal sebagai : hak rakyat). ${ }^{4}$ Dalam perkembangannya saat ini setiap orang wajib dan bertanggungjawab tentang kesehatan (termasuk imunisasi), yang ditandai adanya peran swasta (termasuk profesi dokter praktek swasta) dalam program kesehatan. ${ }^{6}$ Karenanya sifat hukumnya adalah menyelenggarakan upaya kesehatan dalam rangka kesejahteraan umum, melalui (sistem) pemerintahan sebagai tugas administrasi negara, sehingga kajian program imunisasi massal termasuk dalam hukum administrasi negara.

\section{Prinsip Hukum Administrasi Negara (HAN)}

Bertolak dari dasar-dasar bahwa Indonesia adalah negara hukum (rechstaat) ${ }^{6}$ dan batasan bahwa negara merupakan organisasi kekuasaan yang berdaulat, maka pemerintah memiliki kedaulatan negara dalam bidang eksekutif. Pemerintah memiliki kewenangan publik yang tidak bisa didikte siapapun. ${ }^{7}$ Demi menyongsong perkembangan dunia dengan kemajuan iptek serta keperluan (hajat hidup) teknis masyarakatnya, untuk kelenturan dan adaptasinya tak mungkin dibuat peraturan (hukum positif) lebih dahulu. Oleh karena itu pemerintah diberi kemerdekaan kekuasaan bertindak atas inisiatif sendiri untuk mengatasi persoalan khusus dan mendesak yang peraturannya belum sempat dibuat oleh legislatif. Hal ini dikenal sebagai kewenangan diskresioner (freies Ermessen) yang diemban oleh kekuasaan membuat peraturan kebijakan dari pejabat administrasi negara. Namun kewenangan publik yang besar ini harus diimbangi dengan serangkaian etika sosial, prinsip manajemen lege artis dan kebenaran yuridis. Etika sosial dan manajemen lege artis tadi antara lain adalah prinsip AAUPB (azasazas umum pemerintahan yang baik) dan kode etik pejabat pemerintah.

Prinsip HAN lainnya adalah bahwa pemerintah (dan pejabatnya) harus bersikap teliti, hati-hati, hemat dan seksama dalam menyimpan/ merawat harta kekayaan negara, sehingga harus ada pemisahan tegas 
antara kas pejabat selaku individu dengan kas negara. Keputusan yang dibuat pemerintah bertujuan untuk melindungi jiwa, raga dan harta warga masyarakatnya. Prinsip AAUPB dan kode etik pejabat dimaksud untuk mencegah penyalahgunaan wewenang/kekuasaan (detournement de pouvouir).

\section{Azas-azas Umum Pemerintahan yang Baik (AAUPB)}

\section{Kriteria Wiarda}

1. Azas kejujuran (fair play).

2. Azas kecermatan (zorgvuldigheid).

3. Azas kemurnian dalam tujuan (zuiverheid van oogmerk).

4. Azas keseimbangan (evenwichtigheid).

5. Azas kepastian hukum (rechtszekerheid).

\section{Kriteria Le Roy}

1. Prinsip kepastian hukum (rechtszekerheidsbeginsel, principle of legal security).

2. Prinsip keseimbangan (evenredigheidsbeginsel, principle of proportionality).

3. Prinsip kesamaan dalam mengambil keputusan (gelijk heidsbeginsel, principle of equality).

4. Prinsip bertindak cermat atau seksama (zorgvuldingheidsbeginsel, principle of carefulness).

5. Prinsip motivasi untuk setiap keputusan (motiveringsbeginsel, principle of motivation).

6. Prinsip jangan menyalahgunakan kewenangan (verbod van detournement de pouvoir, principle of non-misuse of competence).

7. Prinsip permainan tulus (fair play beginsel).

8. Prinsip keadilan atau larangan bertindak sewenang-wenang (redelijkheidsbeginsel verbod van willekeur, principle of reasonableness or prohibition or arbitrariness).

9. Prinsip pemenuhan pengharapan yang ditimbulkan (principe van opgewekte verwachtingen, principle of meeting raised expectation)

10. Prinsip meniadakan akibat keputusan yang dibatalkan (herstelbeginsel, priciple of undoing the consequences of annuled decision)

11. Prinsip perlindungan pandangan hidup pribadi (principe van bescherming van de persoonlijke levenssfeer, the principle of protecting the personal way of live).

\section{Kriteria Purbopranoto}

Tambahan kriteria Le Roy dengan dua prinsip/azas:

12. Azas kebijaksanaan (sapientia).

13. Azas penyelenggaraan kepentingan umum (principle of public service).

\section{Pengelompokan Azas (Prajudi Atmosudirdjo):}

A. Asas prosedural (proses pengambilan keputusan) yang bila dilanggar: keputusan tersebut batal demi hukum (tak perlu dicek "isi” nya lagi):

1. Pejabat penentu keputusan $\&$ lingkungannya tak boleh ada kepentingan pribadi (langsung atau tidak)

2. Audi et alteram partem : Keputusan yang merugikan/mengurangi hak seseorang/ warganegara tidak boleh diambil sebelum memberi kesempatan mereka membela kepentingannya.Contoh : informed-consent.

3. Konsiderans keputusan faktual benar dan wajib sesuai dengan/pembenar diktum (penetapan) keputusan tersebut.

B. Azas kebenaran faktual (isi/substansi keputusan):

1. Larangan kesewenang-wenangan (willekeur, arbitrary act): tidak mempertimbangkan semua faktor yang gayuh secara lengkap dan wajar/lumrah demi kemakmuran, kebahagiaan dan kesejahteraan rakyat, sifatnya obyektif dan impersonal, keputusan secara akal sehat terasa timpang; digugat perdata (melanggar 1365 KUHP)

2. Larangan penyalahgunaan wewenang

3. Larangan diskriminasi hukum (adil dan impersonal)

4. Kepastian hukum (bila perlu memberlakukan masa peralihan bagi yang akan dirugikan, tidak boleh mendadak dan merugikan bagian terbesar rakyat).

5. Batal akibat kecerobohan pejabat bersangkutan.

Khusus untuk penyelenggaraan tata pemerintahan di Indonesia, azas-azas umum untuk pemerintahan yang baik itu harus disesuaikan dengan pokok-pokok Pancasila dan UndangUndang Dasar 1945. 


\section{Analisis Hukum Program Imunisasi}

1. Subyek hukum (persoonsleer, dalam hal ini ambtenleer):

a. Pejabat pemerintah (Departemen Kesehatan) beserta jajarannya sebagai penanggungjawab personal. Pejabat atribusian (pemilik kewenangan) ialah: Menteri Kesehatan yang dalam hal teknis dilaksanakan oleh Dirjen P2M-PLP yang membuat kebijakan imunisasi tingkat nasional.

b. Departemen Kesehatan (khususnya Ditjen P2M-PLP) sebagai instansi beserta instansi di bawahnya sebagai penanggung-jawab institusional.

Sesuai dengan kewenangan dan tata organisasi Depkes, pejabat delegasian (penerima kewenangan) adalah Kakanwil Depkes atau Kadinkes yang berturutturut adalah di Tingkat Propinsi (Dati I), Tingkat Kabupaten/Kotamadya (Dati II). Pejabat ini sekaligus juga pejabat atribusian (pemilik kewenangan) berdasarkan keputusan Gubernur (Kepala Daerah Tingkat I) atau Bupati/Walikodya (Kepada Dati II) yang membuat kebijakan tingkat daerah masingmasing. Kadinkes akhirnya memberi tugas dan mendelegasikan kewenangannya kepada dokter puskesmas di wilayah masing-masing.

Surat tugas yang umum dari Kadinkes (Dati II) diperlukan, dengan menyebut nama program, nama sasaran, jangka waktu, tempat, pejabat yang ditunjuk dan garis besar tugasnya. Petunjuk teknis medis tugas yang harus dilakukan (standar prosedur operasional) dilampirkan. Dengan demikian dokter puskesmas sah secara hukum sebagai pejabat lapangan yang bertugas untuk melakukan imunisasi di wilayahnya.

Mengingat banyaknya tugas dokter puskesmas, tugas tersebut dapat dilimpahkan kepada sesama dokter di wilayahnya (PTT atau dokter lainnya yang sah) dan atau tenaga kesehatan bawahannya seperti perawat selaku juru imunisasi. ${ }^{10}$ Diperlukan Surat Tugas dari dokter selaku Kepala Puskesmas Kecamatan dan atau Kelurahan yang terinci untuk itu, seperti waktu (jangka tertentu), nama-nama murid dan nama sekolah, lokasi/ tempat imunisasi, vaksin yang dipakai, nomor batch, nama-nama petugas/tenaga kesehatan pemberi imunisasi dengan keterangan kompetensinya, sarana yang diperlukan (termasuk untuk penanggulangan KIPI), dan lain lain. Dengan demikian masing-masing perawat selaku juru imunisasi secara administratif sah memperoleh delegasi program (kewenangan) pemerintah tersebut sesuai dengan kompetensinya.

Rantai tanggungjawab berjenjang memberi pula pola pertanggungjawaban program yang berjenjang, sehingga kesalahan perawat pemberi imunisasi secara vicarious liability pada gilirannya merupakan tanggungjawab Dirjen P2M-PLP.

2. Kekuasaan hukum (gebiedsleer)

a. Terhadap orang: imunisasi dilakukan terhadap masyarakat yakni anak sekolah (sebagai adressat/penerima imunisasi).

b. Terhadap ruang: melalui sekolah-sekolah di wilayah kelurahan dan kecamatan di seluruh Indonesia.

c. Terhadap waktu : setiap tahun (pelaksanaan sesuai waktu yang telah diprogramkan).

d. Terhadap benda: dengan vaksin yang telah diakui secara sah efektif dan efisien yang didistribusikan ke sekolah-sekolah.

Kekuasaan hukum ini yang harus tercermin secara rinci dalam setiap Surat Tugas atau Surat Keputusan pejabat berwenang.

\section{Hubungan hukum (leer de administratieve recht)}

Ada 3 jenis hubungan hukum antara pejabat / tenaga kesehatan dengan murid/anak sekolah terkait yakni:

a. Pelaksanaan imunisasi massal anak sekolah yang telah diprogramkan sebelumnya oleh tenaga kesehatan tertentu yang berkompeten dan berwenang terhadap klien (anak sekolah) yang telah disetujui oleh orangtuanya dengan vaksin yang telah memenuhi standar tertentu melalui sekolah-sekolah sesuai dengan ketentuan hukum yang berlaku. Dalam hubungan hukum ini informed-consent dari orangtua mutlak diperlukan mengingat anak sekolah belum dianggap sebagai pribadi hukum mandiri (belum dewasa). ${ }^{8}$ Materi informed-consent meliputi pula manfaat dan risiko imunisasi seperti KIPI. ${ }^{8}$ Mengingat program ini adalah massal yang dilakukan oleh pemerintah dengan itikad baik maka proses informed-consent dapat ditempuh secara kolektif melalui penyuluhan pra-imunisasi oleh dokter puskesmas kepada para orangtua murid di 
sekolah, dengan bukti berita acara yang dilampirkan daftar hadir serta disaksikan oleh kepala sekolah. Dalam kondisi khusus informed-consent ini dapat berupa implied-consent bila orangtua ikut mengantarkan anaknya di-imunisasi. Setelah proses pemberian informasi, dibuka kemungkinan penolakan oleh orangtua tertentu. Penolakan ini harus tertulis disertai alasan-alasannya. Namun harus disertai pernyataan kewajiban kesediaan si orangtua agar anaknya diimunisasi serupa pada kesempatan atau tempat lain.

b. Penatalaksanaan komprehensif KIPI tahap awal yang timbul akibat hubungan hukum sebelumnya terhadap (sebagian kecil) klien yang telah (berubah status hukum) menjadi pasien. Dalam kondisi tidak gawat/darurat, ditempuh proses informed-consent untuk mengobati anak yang terkena KIPI. Dalam kondisi darurat tidak diperlukan hal itu, langsung saja dilakukan tindakan medis life-saving di Puskesmas setempat atau di fasilitas RS rujukan. Kondisi KIPI adalah khas yang memerlukan kompetensi khusus untuk menegakkan diagnosis. Oleh karena itu diagnosis harus dilakukan oleh dokter. Rekam medis menjadi penting untuk kepastian hukum dan perlindungan hukum bagi dokter maupun pasiennya. Aturan hukum kedokteran yang umum berlaku di sini.

c. Penatalaksanaan komprehensif KIPI tahap lanjut yang timbul akibat hubungan hukum sebelumnya terhadap (lebih sebagian kecil lagi) pasien yang telah (berubah status hukum) menjadi korban. Penatalaksanaan hampir sama dengan butir b., namun agar obyektif, bila diperlukan "surat keterangan medik" harus dilakukan pemeriksaan oleh dokter lainnya atau atasannya. Untuk pasien yang mati dianjurkan untuk otopsi forensik, agar penyebab pasti kematian dapat ditegakkan. Penolakan otopsi oleh keluarga korban harus dicatat dengan disebutkan alasannya. Biaya yang timbul pada kondisi butir b dan c sewajarnya ditanggung (sebagian atau seluruhnya) oleh pemerintah. Namun untuk meneliti keabsahannya perlu suatu verifikasi oleh tim atau lembaga independen, seperti Pokja KIPI, agar mempermudah kerja pemerintah dan terciptanya rasa keadilan bagi korban. ${ }^{?}$

Dari ketiga jenis hubungan hukum ini aspek bidang hukum yang terkait adalah hukum administrasi negara, hukum pidana, dan hukum perdata. Selain itu ada pula hubungan hukum antara pejabat kesehatan dengan pihak lain, baik BUMN maupun swasta dalam hal pembuatan atau pengadaan vaksin, seperti dengan PT (Persero) Biofarma dan lain lain yang aspek hukumnya pada umumnya adalah perdata (dimasukkan ke dalam hal jual/beli perdata).

\section{Anatomi Hukum Administrasi yang Terkait $^{10}$}

1. Peraturan-peraturan yang dibuat oleh Pembentuk UU: ${ }^{15}$

yakni peraturan perundang-undangan (wettelijke regels) mulai dari UU, PP, Keppres delegasian dari PP atau UU, Kepmen, Keputusan LPND, Kep. Dirjen delegasian, Keputusan Badan Negara yang dibentuk berdasarkan atribusi UU, Perda Tingkat I, Kep. Gubernur Kepala Daerah Tingkat I delegasian dari Perda Tingkat I, Perda Tingkat II serta keputusan Bupati/Walikotamadya Dati II delegasian dari Perda Tingkat II. Contoh yang terkait dengan program imunisasi:

- UU Wabah

- UU Kesehatan No. 23/1992

- PP tentang tenaga kesehatan No. 32/1996

- PP tentang P2M-PLP

- SK Menteri terkait

- SK tentang organisasi Ditjen P2MPLP Depkes

- Peraturan Daerah Tingkat I dan II terkait

- SK pengangkatan Dirjen

2. Peraturan yang bukan dibuat oleh Pembentuk Undang-Undang, tetapi dibuat oleh badan-badan administratif (pemerintah / Depkes) berupa peraturan kebijakan. ${ }^{11}$

Peraturan ini disebut sebagai peraturan kebijakan (beleidsregels) yang bersumber pada fungsi eksekutif negara. Contoh yang terkait program imunisasi :

- SK program imunisasi anak sekolah (BIAS)

- SE tentang juklak dan juknis imunisasi (prosedur tetap, model implementasi, dan lain lain)

- SK Pengadaan vaksin dengan proyek tertentu dan anggaran tertentu

- SK Pembentukan KIPI (pusat maupun 
daerah)

- Disposisi Dirjen menugaskan/melibatkan organisasi profesi, Biro Hukum Pemda dan kepala sekolah tertentu untuk membantu penyelesaian kasus KIPI dan lain lain

\section{Syarat "faali" Administrasi Negara yang Berkaitan dengan Program Imunisasi}

1. Efektivitas (doelmatigheid, aktivitas/produk-tivitas mencapai tujuan/sasaran).

Dalam hal ini tujuannya adalah menurunkan angka kematian, kecacatan dan kesakitan penyakit wabah, penyakit karantina dan penyakit yang dianggap sejenis.

2. Legitimitas (keabsahan).

Pemerintah dalam hal ini Dirjen P2M-PLP secara kelembagaan telah dipercaya menyelenggarakan dan menjadi penanggung jawab program imunisasi.

3. Yuridisitas (rechtmatigheid, kesesuaian hukum dalam arti luas, tidak melawan atau melanggar hukum).

Peraturan perundang-undangan positif menunjukkan adanya hal ini, khususnya dari UU Kesehatan, antara lain:

a. Aturan tentang kelembagaan (organische rechtregels)

b. Aturan tentang fungsi administrasi negara (functionele rechtregels)

c. Hal-hal yang dibenarkan secara hukum (jurisdische rechtvaardiging)

4. Legalitas (wetmatigheid, berdasar hukum, terbukti dasar hukumnya).

Dasar hukumnya sama seperti anatomi HAN tentang program imunisasi. Untuk suatu program, umumnya tampak pada bagian "Mengingat" suatu produk hukum keputusan administratif misalnya SK tertentu.

5. Moralitas

Dari kaidah etika kedokteran dan etika pelayanan medis mendasari program ini. Untuk program terkait tampak pada bagian "Menimbang", karena berisi kebijakan hukum yang menjadi dasar program tersebut. Bagi pejabat pelaksana dapat digunakan sebagai pedoman dalam kewenangan diskresioner, khususnya yang belum diatur oleh hukum.

6. Efisiensi (hemat).
Merupakan tolok ukur program ini yang menyatu dengan manajemen program secara umum, dalam standar prosedur operasional, indikator keberhasilan, dan lain lain.

7. Teknis (kualifikasi maksimal mencapai mutu tertinggi).

Hal ini juga menyatu dalam standar prosedur operasional. Segi hukum dari mutu SDM terkait dengan kriteria kompetensi tenaga kesehatan yang bersangkutan yang menjadi dasar dari kewenangannya. Dalam program ini pelaksanaannya dilakukan oleh tenaga medis yang kompeten dalam bidangnya dengan mutu vaksin standar.

\section{Titik Imbang (Keserasian) Syarat Faali}

Aspek efektivitas dan efisiensi (kemanfaatan atau doelmatigheid). Dalam hal ini pencapaian tujuan harus seimbang dengan aspek yuridisitas (rechtmatigheid) dan legalitas (wetmatigheid). Hal ini yang menjadi salah satu tolok ukur PTUN dalam memeriksa kasus sengketa administrasi negara.

\section{Dasar Hukum (Aspek Legalitas) Program Imunisasi Ada di UU Kesehatan No. 23/1992:}

a. Keberadaannya :

Hak pemerintah mengatur bidang kesehatan tercantum pada pasal 6,7 dan 8 yo pasal 30 dan pasal 31 yo pasal 4 ayat 1 UUD 1945 yakni adanya kekuasaan pengaturan secara umum (algemene regeling) yang merupakan bagian dari kekuasaan pemerintahan negara (staatsregering) yang berada di tangan Presiden.

Pasal 30 Pemberantasan penyakit menular dilaksanakan dengan upaya penyuluhan, penyelidikan, pengebalan, menghilangkan sumber dan perantara penyakit, tindakan karantina dan upaya lain yang diperlukan

Pasal 31 Untuk penyakit karantina dan wabah, tunduk pada ketentuan UU terkait.

b. Kaitan dengan pembinaan.

Pembinaan oleh pemerintah terhadap semua upaya kesehatan (pasal 73)

c. Kaitan dengan perlindungan masyarakat Imunisasi merupakan upaya melindungi masyarakat terhadap kemungkinan kejadian gangguan dan atau bahaya kesehatan (pasal 74 
butir 3) dan PP terkait

d. Kaitan dengan peran serta sekolah/ guru dan masyarakat lain

Pasal 71 ayat (1) yo kegiatan Upaya Kesehatan Sekolah : pasal 10 ayat (1) butir l. yo peningkatan kesehatan anak (usia sekolah) : pasal 17 ayat (2) dengan tujuan peningkatan kemampuan hidup sehat dalam lingkungan sekolah sehingga proses pendidikan lancar dan optimal (pasal 45 ayat (1) melalui sekolah atau lembaga pendidikan lain (pasal 45 ayat 2) dilengkapi PP terkait.

e. Kaitan dengan pengadaan vaksin mengenai perbekalan tercantum dalam pasal 60, 61, 62 dan 64 .

\section{Isi Hubungan Hukum}

1. Suatu kewajiban melakukan imunisasi kepada rakyat (anak sekolah)

2. Hak menagih atau meminta laporan pertanggungjawaban dari pejabat pelaksana terkait

3. Ijin atau persetujuan kepada dokter puskesmas beserta tenaga medis bawahannya di lapangan untuk melaksanakan imunisasi dan mengatasi komplikasi berupa KIPI yang terjadi.

4. Pemberian status kepada seseorang atau lembaga/ sesuatu yang menimbulkan hubungan hukum tertentu (yang baru), misalnya:

a. PT (Persero) Biofarma (sebagai BUMN) dan pihak lainnya (bila ada) untuk mengadakan vaksin dan alat/keperluan terkait lainnya.

b. Pejabat di tingkat lebih bawah berturut-turut hingga sampai ke dokter puskesmas sebagai penanggungjawab lapangan untuk melaksanakan imunisasi masal anak sekolah di sekolahsekolah atau tempat lain yang ditunjuk.

c. Kelompok Kerja KIPI Pusat dan Daerah untuk membantu menangani protokol pelaksanaan dan pengaduan atas gugatan KIPI dan penyelesaiannya.

\section{Jenis Tindakan Hukum Publik Program Imunisasi}

1. Penetapan (beschikking, administrative discretion) Berupa SK pengangkatan jajaran Kanwil, Kadinas, Dokter Puskesmas sebagai penanggungjawab kegiatan imunisasi massal setempat dan sesuai jenjangnya ke bawah sampai batas petugas tenaga kesehatan yang kompeten, yakni dokter (sebagai pelaku tindakan medik berupa imunisasi dan KIPI-nya). Oleh karenanya SK pengangkatan ini harus ada terlebih dahulu, dilengkapi dengan fungsi, wewenang dan tanggungjawabnya. Dalam hal terkait juga SK penunjukan sekolah tertentu sebagai tempat penyelenggaraan, dan bila perlu melibatkan kepala sekolahnya sebagai pembantu pemberi informasi.

\section{Rencana (plan)}

Rencana berupa pencanangan BIAS yang telah ditetapkan sesuai program. Sifatnya luas, tertulis dan umum. Rencana ini sifatnya mengikat semua pihak terkait, khususnya di wilayah (daerah) masing-masing.

\section{Norma jabaran (concrete normgeving)}

Tindakan hukum pejabat Depkes membuat peraturan perundang-undangan yang memuat isi yang konkrit dan praktis sehingga laik-terap di waktu dan tempat wilayahnya. Isinya mengikat dan bisa bersanksi hukum. Bentuknya berupa SE (surat edaran), SI (surat instruksi dinas), pengumuman, dan lain lain. dari Kanwil/ Kandepkes dan atau dokter pus-kesmas setempat ditujukan kepada warga setempat.

\section{Legislasi-semu (pseudo-wetgeving)}

Penciptaan aturan hukum oleh pejabat Depkes berwenang sebagai pedoman (richtlijnen), pelaksanaan policy (kebijakan) pelaksanaan perundang-undangan yang dipublikasikan luas. Asalnya dari wewenang kebebasan pertimbangan kebijakan atau diskresioner (freies Ermessen) untuk mengatasi situasi konkrit tertentu di lapangan. Contoh : juklak (petunjuk pelaksanaan) dan juknis (petunjuk teknis), petunjuk lisan ke bawahan, disposisi, dan lain lain dari Kanwil/Kandepkes dan/atau dokter puskesmas setempat.

Bentuk ke 3 dan 4 dimasukkan ke dalam "Peraturan kebijakan (beleidsregels)" yakni peraturan yang menyelenggarakan kebijakan pemerintahan yang tidak terikat (tidak terikat kepada UU/peraturan positif lainnya), berupa kebijakan dari Dirjen maupun pejabat atribusian/delegasian terkait. ${ }^{11}$ 


\section{Wewenang Pengelola Program Imunisasi}

Dirjen P2M-PLP merupakan pihak berwenang dalam pengelolaan program imunisasi. Dasar dari kewenangan ini ialah otonomi pemerintah (dalam rangka kepentingan hukum masyarakat yakni terciptanya derajat kesehatan yang tinggi). Kewenangan Dirjen P2M-PLP sebagai administrasi negara di bidang imunisasi tidak boleh dicampuri oleh pihak manapun.

Perbuatan hukum Dirjen P2M-PLP sebagai penanggung jawab (public authority) dalam program imunisasi menghasilkan wewenang publik:

1. Sebagai pemerintah (penguasa eksekutif):

a. Menghasilkan keputusan pelaksanaan / eksekutif / pemerintahan di bidang imunisasi

b. Penegakan UU Wabah dan UU Kesehatan terkait atau wibawa negara secara umum agar negara tetap diakui sebagai alat untuk menyejahterakan rakyatnya.

2. Sebagai administrator negara (penguasa administratif):

a. Menghasilkan keputusan administratif (TUN) di bidang imunisasi : misalnya pengangkatan pejabat / petugas imunisasi, Pokja KIPI, pengadaan vaksin, penelitian vaksin, dan lain lain.

b. Melaksanakan keputusan penyelenggaraan atau realisasi di bidang imunisasi: misal pencanangan BIAS dengan targetnya setiap tahun, dan lain lain.

Sifat wewenang publik yang dalam hal ini dipegang oleh pemerintah (Ditjen P2M-PLP dan jajarannya) adalah kekuasaan luar biasa (tidak bisa dilawan dengan jalan biasa, tetap harus melalui jalan khusus yakni gugatan ke peradilan TUN).

\section{Jenis wewenang publik yang dimiliki ${ }^{12}$}

1. Wewenang prealabel: melaksanakan ke-putusan yang telah diambil sendiri tanpa meminta terlebih dulu persetujuan instansi atau perorangan manapun.

2. Wewenang ex-officio: membuat putusan berdasarkan jabatan (beberapa atas dasar sumpah jabatan), yang tidak bisa dilawan siapapun, dilindungi negara (yang melawan diberi sanksi pidana : pasal 160, 161, 211, 212, 216 KUHP).
Mengingat demikian besar wewenang pemerintah, maka sering muncul bahaya hukum yakni penyalahgunaan wewenang/kekuasaan (detournement de pouvoir, ultra-vires). Pembatasan penyalahgunaan kewenangan tersebut pada pokoknya adalah berupa penjabaran azas legalitas dan yuridisitas.

\section{Aspek Hukum Pelaksanaan Program di Lapangan}

Kemajuan iptek kedokteran dan kebutuhan pelayanan kesehatan masyarakat di wilayah Indonesia yang plural akan mempengaruhi pelaksanaan imunisasi. Pelaksanaan di lapangan yang beragam tidak selamanya harus sesuai dengan peraturan perundang-undangan yang berlaku. Hal ini memungkinkan Ditjen P2M-PLP dan jajarannya lebih leluasa dalam membuat peraturan kebijakan tentang program tersebut sesuai dengan situasi dan kondisi setempat. ${ }^{10}$

\section{Persyaratan peraturan kebijakan}

- Tidak boleh bertentangan dengan peraturan dasar yang mengandung wewenang diskresioner yang dijabarkannya

- Tidak boleh nyata-nyata bertentangan dengan nalar sehat

- Harus dipersiapkan dengan cermat. Kalau perlu sebelumnya dimintakan advis teknis dari instansiinstansi berwenang terkait, diadakan rembukan dengan pihak terkait dengan keputusan TUN yang bersangkutan, dilengkapi pertimbangan semua kepentingan, keadaan-keadaan serta alternatifalternatif yang ada

- Isi yang dirumuskannya harus cukup mem-berikan kejelasan mengenai kewajiban-kewajiban dan hakhak warga yang terkena serta harus ada kepastian mengenai tindakan-tindakan yang akan dilakukan oleh instansi yang bersangkutan (kepastian hukum formal)

- Pertimbangannya, walau tidak rinci, namun memuat jelas tujuan-tujuan serta dasar-dasar ditempuhnya kebijakan itu

- Harus memenuhi syarat kepastian hukum material, artinya hak-hak dari warga masyarakat yang terkena harus dihormati, kemudian juga harapan-harapan yang telah diberikan jangan sampai diingkari. 
Bila mengalami kesulitan dalam operasionalisasi dan implementasi di lapangan, Dirjen P2M-PLP beserta jajarannya hingga ke dokter puskesmas lapangan berhak melakukan kebijakan diskresioner. ${ }^{13}$ Diskresi merupakan kebebasan untuk melakukan penilaian (kebebasan pertimbangan) dalam hukum pada suatu situasi yang mana pengambilan suatu keputusan pemerintah tidak diatur oleh suatu peraturan hukum. ${ }^{22}$ Artinya instansi pemerintah, dengan melihat pada situasi faktual masyarakat, memiliki kebebasan untuk menentukan sendiri keputusan apa, kapan, dan yang bagaimana yang akan dikeluarkan. Wewenang diskresioner tidak boleh dibatasi oleh norma hukum tertulis maupun yang tidak tertulis.

Dalam hal imunisasi antara lain ialah kewenangan menetapkan atau menolak seorang anak diimunisasi (setelah menarik kesimpulan kontraindikasi "relatif" seperti ada tidaknya demam dan lain lain), membebani kewajiban kepada orangtua yang menolak anaknya diimunisasi untuk melakukannya di sarana kesehatan lainnya, memberikan atau tidak memberikan pelayan-an khusus/ekstra kepada pasien/korban, pemberian "santunan" pada korban KIPI, pemilihan waktu imunisasi yang tidak harus pagi hari sebagaimana dianjurkan, sampai ke pembatalan dipakainya sekolah tertentu. Kewenangan diskresioner ini dikaitkan dengan otonomi profesi, dapat digunakan sebagai langkah khusus memodifikasi standar profesi yang kurang terinci, asalkan langkahnya rasional (dapat dipertanggungjawabkan secara ilmiah), adil dan hanya demi kepentingan klien/pasien (sikap berbuat baik). Contoh: melakukan tindakan pencegahan awal KIPI, perubahan RS rujukan, penganjuran otopsi bagi kasus meninggal, menghubungi teman sejawat terdekat untuk meminta second-opinion diagnosis KIPI yang meragukan, dan lain lain.

\section{Tanggunggugat pasien/ korban KIPI}

Dokter puskesmas selaku pejabat lapangan maupun pejabat Depkes lainnya (atasannya, selaku responden superior) bisa digugat bila melakukan penyimpangan:

a. Administratif : digugat PTUN

b. Pidana : pelanggaran jabatan dalam KUHP

c. Perdata : menimbulkan kerugian warga masyarakat (dalam hal ini korban KIPI).
Dalam hal penyimpangan administratif, sebelum diajukan ke PTUN, terlebih dahulu ditempuh prosedur administratif yang telah ditetapkan oleh pejabat Depkes yang berwenang. Misalnya ketentuan prosedur pengajuan tuntutan oleh orangtua pasien/ korban KIPI yang umum-nya diatur secara berjenjang dengan prinsip subsidiaritas (yang bisa diselesaikan oleh kelompok bawahan tidak perlu diselesaikan oleh atasan/pusat). Prosedur tersebut harus diatur dalam keputusan atau penetapan pejabat Depkes demi rasa keadilan masyarakat dan maraknya isu penegakan hakhak asasi manusia. Prosedur tersebut juga menampung rujukan bila mereka belum menerima putusan atau kebijakan yang diberikan. Dengan pendekatan persuasif, yang melibatkan peer's group dan rapinya ketentuan peraturan maupun kebijakan secara hukum, akan sulit membawa dokter/perawat atau pejabat Depkes lainnya ke PTUN.

\section{Delik pidana jabatan dalam KUHP ialah:}

a. Pasal 415 : penggelapan uang/surat berharga

b. Pasal 417 : peniadaan (hilangkan, gelapkan) barang bukti, akta, surat, daftar dan lain lain sehingga membuat penetapan tidak adil, tidak betul dan lain lain

c. Pasal $418 \& 419$ : menerima hadiah/janji

d. Pasal 421 : menyalahgunakan kekuasaan untuk memaksa seseorang berbuat/tidak berbuat/ membiarkan sesuatu

e. Pasal 422 : menggunakan sarana paksaan untuk memeras pengakuan/memperoleh keterangan

f. Pasal 425 : pemerasan

g. Pasal 429 : memaksa masuk pekarangan/rumah tertutup tanpa ijin penghuni yang berhak, tidak segera meninggalkannya setelah diminta penghuni, tanpa ijin memeriksa/merampas surat-surat, bukubuku, dan lain lain.

h. Pasal 435 terlibat KKN dalam pemborongan, penyewaan dan lain lain dalam lingkup tugasnya.

Dalam penyimpangan pidana, selain delik jabatan, dimungkinkan secara strict liability menuntut dokter atau perawat penyuntik vaksin, bila terbukti tidak bekerja secara teliti/hati-hati, tidak ada indikasi medik (ada kontraindikasi medik namun tetap diimunisasi), tidak sesuai dengan standar profesi dan standar pelayanan dan tidak ada informed-consent. Kriteria malpraktek seperti duty, deriliction of duty, damages, 
direct causational of damages (4-D) harus dipenuhi secara kumulatif. Rangkuman hal-hal tersebut di atas harus memenuhi rumusan delik pidana seperti kelalaian yang menyebabkan sakit berat/cacatnya (pasal $360 \mathrm{KUHP}$ ) atau matinya orang lain (pasal 359 KUHP). Di samping itu aspek hukum pidana yang bisa dikenakan kepada tenaga kesehatan antara lain pasal $378 \mathrm{KUHP}$ tentang penipuan terhadap penderita atau pasien; tentang pembuatan surat keterangan palsu (pasal 263 dan 267 KUHP); kesengajaan membiarkan penderita tidak tertolong (pasal 349 KUHP); tidak memberikan pertolongan pada orang yang berada dalam bahaya maut (pasal $267 \mathrm{KUHP}$ ); pelanggaran kesopanan (pasal 290 ay.1, pasal 294 ay.1, pasal 285 dan 286 KUHP); memberikan atau menjual obat palsu (pasal 386 KUHP). ${ }^{14}$ Unsur kesengajaan (opzet) dokter atau perawat penyuntik juga harus dibuktikan. Dengan demikian sepanjang bekerja sesuai standar prosedur, kejadian KIPI apapun sulit memperkarakan dokter/ perawat secara pidana dalam kasus imunisasi.

\section{Gugatan Perdata}

Yang digugat adalah penetapan pejabat Depkes yang sampai menimbulkan kerugian. Pada gugatan ini perlu pembuktian adanya unsur melawan hukum (onrechtmatig), yakni bila:

a. Keputusan tidak / kurang mengindahkan, diambil secara bertentangan dengan perundang-undangan

b. Detournement de pouvoir: menyalahgunakan wewenang, menyimpang dari tujuan pemberian wewenang.

c. Keputusan secara sewenang-wenang (ceroboh, tidak sesuai standar prosedur operasional atau data yang sesuai).

Pertanggungjawaban perdata tenaga kesehatan ada dua bentuk yakni atas kerugian pasien yang disebabkan oleh karena wanprestasi, dan pertanggungjawaban atas kerugian yang disebabkan karena perbuatan melawan hukum. ${ }^{15}$ Hak menuntut ganti rugi pasien ini diatur dalam pasal 55 ayat (1) UU Kesehatan No. 23/1992.

Wanprestasi adalah suatu keadaan seseorang (dokter) yang tak memenuhi kewajibannya yang ditentukan pada suatu kontrak/ perjanjian. Yang dijanjikan dokter dalam hal ini adalah mewujudkan suatu usaha atau daya upaya secara maksimal.
Wanprestasi terjadi ketika pihak yang berjanji tak memenuhi prestasi sama sekali, terlambat atau memenuhi prestasi secara buruk. Pengertian perbuatan melawan hukum dalam arti luas mencakup pengertian berbuat atau tidak berbuat, yang melanggar hak orang lain dan bertentangan dengan kewajiban hukum sendiri atau kesusilaan/ kepatutan. Dengan kata lain, perbuatan itu harus mencakup: karena melawan hukum (onsrechtmatige daad), karena menimbulkan kerugian, dan atau karena antara perbuatan dan kerugian tersebut terdapat hubungan kausal.

Suatu pertanggungjawaban perdata bertujuan untuk memperoleh kompensasi atas kerugian yang diderita yang menjadi pangkal tolak atau dasar menggugat dokter. Dasar hukum per-tanggungjawaban perdata tersebut didasarkan atas tiga pasal yang terdapat dalam Kitab Undang Undang Hukum Perdata (KUHPer) yo pasal 55 ayat (2) UU Kesehatan No. 23/1992. Ketiga pasal tersebut dipakai sebagai dasar dalam menentukan ada atau tidaknya kewajiban dokter (terhadap pasien) dengan segala implikasinya. ${ }^{16}$ Pasal-pasal tersebut ialah:

- Pasal 1365 KUHPer: setiap tindakan yang menimbulkan kerugian atas diri orang lain berarti bahwa orang yang melakukannya harus membayar kompensasi sebagai pertanggungjawaban kerugian

- Pasal 1366 KUHPer: seseorang harus bertanggungjawab tidak hanya karena kerugian yang dilakukannya dengan sengaja, tetapi juga karena kelalaian atau kurang berhati-hatinya

- Pasal 1367 KUHPer: seseorang harus memberikan pertanggungjawaban tidak hanya atas kerugian yang ditimbulkan dari tindakan orang lain yang berada di bawah pengawasannya

Tuntutan perdata mungkin akan sama seringnya dengan tuntutan administratif. Namun sebelumnya harus terlebih dahulu dibuktikan bahwa tenaga kesehatan lalai (kriteria seperti di tuntutan pidana). Halhal seperti syok anafilaktik dan kejadian KIPI lainnya sepanjang telah dilakukan tindakan medik sebatas upaya maksimal dengan standar kemampuan tenaga kesehatan rata-rata, tak bisa dituntut karena dianggap sebagai kecelakaan atau kemelesetan medik. ${ }^{27}$ Adanya standar rata-rata menyiratkan adanya kewenangan organisasi profesi, sehingga pelibatan organisasi profesi seperti IDI (dengan jajarannya seperti IDAI, PDFI, PERDAFKI, dan lain lain), PPNI, ISFI akan memberi ketenangan bekerja bagi dokter puskesmas di daerah, karena dalam organisasi profesi selalu ada Badan Pembelaan Anggota. 


\section{Penyelesaian Sengketa}

A. Litigasi (melalui peradilan, yakni: PTUN)

Hakim PTUN terbatas hanya meneliti azas yuridisitas keputusan/tindakan hukum/peraturan kebijakan HAN pejabat (rechtmatigheid, segi kesesuaian hukumnya).

Titik berat tindakan adalah pemeriksaan lisan pejabat. Hakim aktif membela warga masyarakat yang titik imbang hukumnya lebih lemah dibandingkan pejabat.

B. Non Litigasi:

1. Internal Departemen Kesehatan:

- Via "Badan Peradilan Semu", misal MDTK (Majelis Disiplin Tenaga Ke-sehatan) sesuai dengan Keppres No.56 Tahun 1995 yo pasal 54 ayat (2) dan (1) UU Kesehatan No. 23/1992.

- Via pejabat/instansi atasan: misal Ankum (atasan berhak menghukum pada ABRI).

- Via Panitia/Tim Khusus : misal Pokja KIPI.

2. Eksternal Intansi Administrasi Negara:

- Via badan arbitrase (internasional)

\section{Tim Khusus seperti Pokja KIPI memiliki keuntungan sebagai berikut:}

- Melancarkan tugas pemerintah (karena sudah cukup sibuk dengan tugas rutinnya) dan kategori KIPI pada hakekatnya merupakan masalah profesional kedokteran (amat sarat dan terkait dengan iptekdok dan praktek kedokteran). Tim akan membantu memberikan analisis secara lebih bebas namun profesional untuk akhirnya mem-berikan rekomendasi penyelesaian kasus.

- Bisa merekrut para profesional dan ahli yang terkait yang tidak dimiliki aparat pemerintah seperti dokter (dengan beragam spesialisasi), sarjana hukum, ahli farmasi, sarjana komunikasi, dan lain lain.

- Membantu agar pemerintah tidak "hilang muka" dan "mau menang sendiri" (khususnya saat ini yaitu saat kredibilitas pemerintah agak turun). Rekomendasi tim akan menjadi pendukung kebijakan pemerintah dari segi ilmiah dan profesional.

- Perlu syarat ketat seperti:

a. Instruksi yang tegas mengenai tugas, we- wenang, kewajiban dan tanggung-jawabnya (misalnya kewenangan pe-nentuan kasus termasuk KIPI atau tidak)

b. Prosedur penyelesaian yang harus ditem-puh (termasuk penyelesaian internal administratif dan rujukan/banding putusannya bila belum selesai)

c. Sanksi bagi anggota tim yang tidak menjalankan butir a.

d. Penampungan akibat/konsekuensi ke-putusan panitia beserta pelaksanaannya, serta bila butir c. terjadi (misalnya kebijakan pemberian "santunan" pada korban).

Walaupun diperiksa oleh instansi internal Depkes pemeriksaan harus dilakukan secara teliti namun adil, dengan tolok ukur pelbagai standar profesi dan pelayanan medik serta pedoman/model implementasi yang telah dibakukan. Terhadap tenaga kesehatan yang terbukti bersalah, khususnya dari segi profesionalitas dan etika pelayanan medik, harus dilakukan sanksi administratif yang diberikan oleh pejabat/instansi atasan, karena upaya ini akan efektif. Selain itu, bila pada pemeriksaan ternyata diperoleh adanya kesalahan "sistem" (di luar tanggungjawab tenaga kesehatan: seperti kondisi vaksin, atau alat suntik dan perlengkapan penunjang lainnya, pejabat atasan akan efektif pula dalam mengubah peraturan atau pedoman/model implementasi terkait. Dari pihak masyarakat luar bisa didapat kesan bahwa sanksi yang dijatuhkan dianggap tidak adil karena dugaan kesejawatan/kesetiakawanan dalam arti negatif (KKN).

Dari segi hukum administratif, sanksi bagi pejabat kesehatan yang bersalah secara perorangan dapat berupa peringatan, teguran dan rekomendasi pencabutan ijin atau kewenangan melakukan imunisasi (bila berat bahkan bisa pencabutan ijin dokternya, sebagaimana ditetapkan oleh MDTK). ${ }^{28}$ Terhadap penanggungjawab program (secara institusional) bisa dilakukan eksekusi riil akibat pelanggaran terhadap ijin yang diberikan dan atau melakukan sesuatu di luar ijin seperti pengamanan/penyitaan vaksin dan alat suntiknya, eksekusi langsung (parate executie) misalnya penarikan pajak, piutang, dan lain lain. Juga dilakukan denda administratif serta pencabutan kembali ijin operasional program di wilayahnya (sebelumnya diperingatkan secara tertulis via surat tercatat atau melalui jurusita, disertai penjelasan mengenai alasannya). 


\section{Otonomi Daerah dan Globalisasi}

Beberapa saat lagi akan berlaku UU tentang Otonomi Daerah, di antaranya bidang kesehatan akan didesentralisasikan ke Dati I dan atau Dati II. Namun mengingat imunisasi bertujuan menghapuskan penyakit wabah, karantina dan penyakit menular lainnya yang di era globalisasi juga tak mengenal batas negara, otomatis penanggulangannya lebih sering lintas propinsi atau lintas daerah. Pengelolaan imunisasi (termasuk KIPI-nya) agaknya masih lebih efektif dan efisien bila tetap terpusat. Diharapkan peraturan perundang-undangan yang mengatur-nya juga harus mengantisipasi masyarakat modern atau masyarakat madani yang berciri-ciri minimal 5 kualitas, yakni stabilitas, peramalan (predictability), adil (fairness), pendidikan (education) dan profesionalitas. ${ }^{17}$ Hak-hak klien (konsumen) ${ }^{30}$ serta hak-hak dasar pasien yakni hak atas penentuan nasib sendiri dan hak atas informasi harus diperhatikan lebih seksama. Hal ini sejalan dengan konsep terkini dari pemerintah sebagai reinventing government.

\section{Daftar Pustaka}

1. Agus Purwadianto. Reformasi hukum kesehatan. Disampaikan dalam: Seminar Tracee II Orde Baru Universitas Indonesia, 30 Maret-1 April 1998.

2. Agus Purwadianto. Aspek hukum bagi tenaga kesehatan di era global. Perlindungan dan realisasi. Disampaikan dalam: Seminar Nasional LKMI-PB HMI, Malang, 1314 September 1997.
3. Monograf Pokja KIPI Pusat. 1999.

4. Amrah Muslimin. Sistem, isi dan beberapa persoalan mengenai hukum administrasi/tata usaha negara," Pidato Pengukuhan Gurubesar Fakultas Hukum Universitas Negeri Sriwijaya, Palembang, 10 Februari 1970.

5. Undang-undang tentang kesehatan, UU No. 23 Tahun 1992, TLN No. 3495 Tahun 1992. Pasal 1 butir 2 (Ketentuan Umum).

6. Dasar falsafah negara: Pancasila, dasar konstitusi: UUD 1945, dasar operasional: GBHN yang memuat wawasan nusantara dan ketahanan nasional.

7. UUD 1945 dengan kekuasaan yang begitu tinggi pada lembaga kepresidenan (pasal 4 dan 5). Dikutip oleh Amrah Muslimin 1970.

8. Permenkes No. 585/1989.

9. Agus Purwadianto. Penanganan sengketa medik. Disampaikan dalam Seminar FH-FK Trisakti 1997.

10. Attamimi H. Hukum tentang peraturan perundangundangan dan peraturan kebijakan (Hukum Tata Pengaturan, FHUI, Jakarta, 1993).

11. Girindro Pringgodigdo. Kebijaksanaan, hirarkhi perundang-undangan dan kebijaksanaan dalam konteks pengembangan hukum administrasi negara di Indonesia. (Pidato Pengukuhan Gurubesar Fakultas Hukum Universitas Indonesia), Depok, 16 Nopember 1994.

12. Atmosudirdjo P. Hukum administrasi negara. Ghalia Indonesia. Jakarta 1988.

13. Indroharto. Perbuatan pemerintahan menurut hukum publik dan hukum perdata. (Bogor - Jakarta: Lembaga Penelitian dan Pengembangan Hukum Administrasi Negara, 1995), hlm. 40-1.

14. Soerjono Soekanto. Hukum kesehatan, Kursus dasar Ilmu hukum kesehatan, Perhuki, Jakarta, 1989.

15. Guwandi. Dokter dan rumah sakit, FKUI, Jakarta 1993; hlm. 39-40.

16. Guwandi. UU RI No. 23. Dalam: Undang-Undang Kesehatan 1992. Jakarta: Sinar Grafika 1993. 